\title{
Effect of organic and conventional farming system and sowing date on yield, seed oil and protein content in rapeseed cultivars
}

\author{
Sreten Terzić* · Ana Marjanović Jeromela · Miroslav Zorić · Vladimir Sikora · Željko Milovac · \\ Petar Mitrović · Igor Balalić · Velimir Radić
}

Institute of Field and Vegetable Crops, Maksima Gorkog 30, 21000 Novi Sad, Serbia

\begin{abstract}
Summary: Rapeseed is one of the major oil crops, grown in various agroecological conditions. Interest in organic rapeseed is rising, with increasing importance to breeders to determine the need for specific organic breeding programs. The objective of this study was to determine the adaptive value of rapeseed cultivars in organic farming environments. Five winter rapeseed cultivars were grown in conventional and organic plots, each with three sowing dates in four replications. The trials were organized using a randomized block design. The effect of cultivar and farming on emergence, percentage of harvested plants, yield, oil and protein content were investigated. Locally recommended agricultural practices were used to keep the fields free from weeds, insects and diseases. In organic field, weeds were removed mechanically while insects were treated using organic insecticide. The seed samples for analysis of oil and protein content were taken during harvest. Considering agricultural practices, it was found that rapeseed can be successfully grown in organic agriculture, but further improvements are needed to increase stability of production. Early sowing date provides enough time for rapeseed growth before the winter and good overwintering. The cultivars had higher oil content in the conventional farming, while there was no significant effect of farming system on protein content. For cultivar Slavica, higher yield was recorded in organic system, while cultivars Banaćanka and Nena had high yield in both farming systems. The results suggest that the existing conventional breeding material can be used as a good starting point for further trait improvements in organic farming.

Key words: conventional, oil, organic, protein, rapeseed, seed yield, sowing date
\end{abstract}

\section{Introduction}

Rapeseed (Brassica napus L.) is an important source of oil for various purposes, being the third-leading source of vegetable oil in the world. It is also regarded as an excellent rotation crop for improving soil quality (Bernard et al., 2012).

In organic agriculture, rapeseed is used for oil production and protein supplements for organic milk production (Khalili et al., 1999; Johansson and Nadeau, 2006), but is also found useful as a cover crop providing

\section{Corresponding author:}

sreten.terzic@ifvcns.ns.ac.rs

Acknowledgments:

This research is financed by the Ministry of Education, Science and Technological Development of the Republic of Serbia as a part of the grant number: 451-03-68/2020-14/ 200032 for the year 2020.

Cite this article:

Terzić S., Marjanović Jeromela A., Zorić M., Sikora V., Milovac Ž., Mitrović P., Balalić I., Radić V. (2020). Effect of organic and conventional farming system and sowing date on yield, seed oil and protein content in rapeseed cultivars. Ratar: Pourt., 57 (2), 55-60. greater than $80 \%$ soil coverage (Haramoto and Gallandt, 2004). Most Brassica species release chemicals that can be toxic to nematodes, fungi and some weeds, though the efficiency of their pest management application is variable and relatively low (Smith et al., 2005). The use of green manure is recommended in organic farming, so that various species are used, while Brassica plants decompose quickly and improve the seedbed for planting (Clark, 2007). The ecological impacts of different farming systems should not be neglected. It was found that pollination deficit (as the difference between actual and potential pollination) is getting higher as the farming intensity is increasing from organic through conventional to GM rapeseed fields (Morandin and Winston, 2005). Transition from conventional to organic agriculture provides not only healthier food, but also a reduction in product environmental footprint. In a study of four major field crops in Canada, canola (Brassica rapa), corn (Zea mays), soybean (Glycine max), and wheat (Triticum aestivum) it was found that organic crop production would consume, on average, 39\% more energy (Pelletier et al., 2008). That reduction was almost completely due to the 
difference in fertilizers used in conventional and organic farming. Knowledge of rapeseed varieties performance in organic production conditions can be useful to both breeders and farmers to determine the need for specific organic breeding programs. The production area and demand for organic rapeseed is steadily growing, while there is relatively few published research results on the subject. As far as we know, this is the first report on comparing organic and conventional rapeseed farming systems in South-East Europe.

The objectives of this study were to (1) compare rapeseed cultivars performance in conventional and organic farming systems, and (2) investigate the influence of farming systems and sowing dates on percentage of emergence, percentage of harvested plants, seed yield and seed oil and protein content.

\section{Material and Methods}

\section{Plant material and field experiment}

In order to investigate the effects of a farming system on the selected parameters, five winter rapeseed cultivars were used: Banaćanka, Slavica, Nevena, Kata and Jasna in conventional and organic farming systems. All cultivars were 00 type, bred at the Institute of Field and Vegetable Crops in Novi Sad, Serbia. They were grown during 2013/2014 season in organic and conventional farming system, each in three sowing dates using block design in four replications.

An organic agricultural practice for rapeseed was developed based on the literature data, organic farmers' experience and adaptation of the locally recommended conventional agricultural practice. In the organic field, weeds were removed mechanically and manually, while insects were treated using an organic insecticide Roball (plant oil mixture).

Sowing dates (SD) were selected as ten day intervals 28 August, 10 September and 18 September 2013. The trials were located in Bački Petrovac $\left(45^{\circ} 20^{\prime} 31^{\prime \prime N} ; 19^{\circ}\right.$ 39'54"E; altitude $79 \mathrm{~m}$ ) on chernozem soil. Rainfall sum for 2013/2014 growing season was $340 \mathrm{~mm}$, close to half of average of $643 \mathrm{~mm}$ for the period 2000-2012. Both fields were irrigated as needed to maintain optimum plant growth.
Fertilizer application was planned according to the soil analysis of samples taken at depth of $30 \mathrm{~cm}$ and incorporated residues of the preceding crop (Tables 1 and 2.). In order to avoid nitrogen depression, $8 \mathrm{~kg}$ of $\mathrm{N}$ was added per $1 \mathrm{t}$ of the preceding crop residues which was incorporated. Organic source of N (DIX $10 \mathrm{~N}$ ) was used in the organic field. Tillage was used for incorporating fertilizers in both farming systems. Commercially available organic fertilizers Italpollina (4:4:4) and DIX 10N (10:3:3) were used in organic plots, while Dueto $(3: 3: 7)$ and Urea N46 were used in conventional plot.

\section{Weed management}

The organic field was generally more occupied by weeds than conventional field. Voluntary plants of the preceding crops were observed. The conventional field was treated with metazachlor (Butisan $0.5 \mathrm{l} / \mathrm{ha}$ ), a herbicide for the suppression of grass and broadleaf weeds by spraying after sowing and pre emergence. Due to the presence of creeping thistle (Cirsium arvense L.) and voluntary plants of wheat, the conventional field was treated with herbicides clopyralid Loret300 (Loret300 0.3 l/ha) and cycloxydim (Focus ultra 2 1/ha) on 21 October 2013. The empty space between plots was kept clean mechanically.

\section{Insect management}

Organic field was treated with plant oil mixture (Roball) insecticide used for organic agriculture. The need for treatment was based on known economic thresholds for rapeseed pests like pollen beetle (1.5-2 beetles/plant) (Štrbac, 2005). First visible leaf damage was observed on 17 September resulting from flea beetles which made holes on cotyledons and turnip sawfly larvae (Athalia rosae) which fed on leaves. The plants were treated successfully by applying Roball (2 l/ha) on 21 September. Roball (2 l/ha) was applied once again on 31 March due to the observed presence of pollen beetle (Meligethes aeneus) above the threshold of economic importance ( 3.6 beetles/plant).

Conventional field received $0.05 \mathrm{l} / \mathrm{ha}$ bifenthrin (Fobos) insecticide after sowing on 21 September. In the spring, due to the presence of pollen beetle (5.2) foliar treatment with bifenthrin was applied on 31 March.

Table 1. Results of soil analysis

\begin{tabular}{cccccccc}
\hline \multirow{2}{*}{ Sample } & \multicolumn{2}{c}{$\mathrm{pH}$} & $\mathrm{CaCO}_{3}$ & Humus & Total & $\mathrm{AL}_{-} \mathrm{P}_{2} \mathrm{O}_{5}$ & $\mathrm{AL}-\mathrm{K}_{2} \mathrm{O}$ \\
\cline { 2 - 8 } & in $\mathrm{KCl}$ & in $\mathrm{H}_{2} \mathrm{O}$ & $(\%)$ & $(\%)$ & $\mathrm{N}(\%)$ & $(\mathrm{mg} / 100 \mathrm{~g})$ & $(\mathrm{mg} / 100 \mathrm{~g})$ \\
\hline Organic field & 7.39 & 8.25 & 6.65 & 3.07 & 0.210 & 52.5 & 39.5 \\
Conventional field & 7.52 & 8.23 & 10.39 & 2.58 & 0.192 & 43.0 & 34.5 \\
\hline
\end{tabular}

Table 2. Amount of nutrients applied to organic and conventional field

\begin{tabular}{|c|c|c|c|c|c|c|c|c|c|c|}
\hline \multirow[t]{2}{*}{ Sample } & \multirow{2}{*}{$\begin{array}{l}\text { Preceding } \\
\text { crop }\end{array}$} & \multicolumn{3}{|c|}{$\begin{array}{c}\text { Autumn fertilization } \\
(\mathrm{kg} / \mathrm{ha})\end{array}$} & \multicolumn{3}{|c|}{$\begin{array}{l}\text { Spring fertilization } \\
\text { (kg/ha) }\end{array}$} & \multicolumn{3}{|c|}{$\begin{array}{l}\text { Total } \\
(\mathrm{kg} / \mathrm{ha})\end{array}$} \\
\hline & & $\mathrm{N}$ & $\mathrm{P}_{2} \mathrm{O}_{5}$ & $\mathrm{~K}_{2} \mathrm{O}$ & $\mathrm{N}$ & $\mathrm{P}_{2} \mathrm{O}_{5}$ & $\mathrm{~K}_{2} \mathrm{O}$ & $\mathrm{N}$ & $\mathrm{P}_{2} \mathrm{O}_{5}$ & $\mathrm{~K}_{2} \mathrm{O}$ \\
\hline Organic field & Spelt* & 40 & 40 & 40 & 100 & 30 & 30 & 140 & 70 & 70 \\
\hline Conventional field & Wheat & 40 & 25 & 60 & 110 & - & 25 & 150 & 25 & 85 \\
\hline
\end{tabular}

*After harvest crop residues incorporated 


\section{Experimental design, laboratory analysis}

The trials were organized using a randomized block design in four replications. The effect of cultivar, farming system and sowing date on emergence, percentage of harvested plants, yield, oil and protein content were investigated. Percentage of harvested plants was calculated by comparing number of plants at harvest with number of plants after emergence. Each basic plot was $7 \mathrm{~m}^{2}$ and consisted of seven rows $4 \mathrm{~m}$ in length, with $0.25 \mathrm{~m}$ spacing. Crops were sown manually with a seeding rate 80 seeds $/ \mathrm{m}^{2}$, and harvested manually when most of the plants reached second technical level of maturity (Harper and Berkenkamp, 1975). Seed oil content was determined using NMR (Nuclear Magnetic Resonance), while seed protein content was determined using Kjeldahl method based on the total N. The yield was calculated at 9\% moisture and expressed as $\mathrm{kg}$ per plot $\left(7 \mathrm{~m}^{2}\right)$.

\section{Statistical analysis}

Data were analysed using the Statistical Analysis System package (SAS Institute Inc., 2010). Due to variation in observed number of plants (n) that was in some cases significantly less than the optimal 560 plants/basic plot $(\mathrm{N})$, their ratio was used to obtain a more reliable analysis of obtained data. The GENMOD procedure was used to fit generalized linear model (GLM), as defined by Nelder and Wedderburn (1972). Logit link function and binomial distribution was used for fitting $\mathrm{n} / \mathrm{N}$, while $\log$ function and Poisson distribution were used for emergence and percentage of harvested plants. Seed yield, seed oil and protein content data were submitted to analysis using the GLM procedure to test the significance of applied factors of cultivar, farming system and sowing date. Tukey grouping was used to determine significantly different factor groups based on minimum significant difference (MSD).

\section{Results and discussion}

Considering all agricultural practices that form a farming system, impact of individual ones, like improving soil fertility, can be different in organic and conventional agriculture. Plants develop in almost ideal conditions in conventional farming, usually having minimal competition for nutrients and space. On the other hand, in organic farming, nutrients and space can have more impact on yield variation due to persistence of weeds or prior crop voluntary plants. According to a wide survey of organic farmer's fields in France, high plant density tends to decrease the damage or the attack of major rapeseed damaging insects. The nitrogen availability in the soil has significant effect on plant vigour and the ability of plants to compensate pollen beetle damage (Valantin-Morison et al., 2007).

\section{The effect of cultivar on percentage of emerged and harvested} plants, seed yield, oil and protein content

Seed yield was found to have highly significantly depended on farming type and sowing date, while oil content was significantly dependent on farming type, sowing date and genotype. Significant interaction was only found between sowing date and farming type for seed oil content (Tab. 3).

Even though cultivar usually has significant effect on seed yield, it was not the case in this trial (Table 3). In conventional farming cultivars Banaćanka, Nena and Kata had similar yields, almost twice higher than Slavica and Jasna (Tab. 4). Slavica is an older and highly adaptive cultivar which explains its good performance in organic conditions. Banaćanka has similar genetic background, while Jasna has both Slavica and Banaćanka in its pedigree (Marjanović-Jeromela et al., 2011). The necessity to use cultivars developed specially for organic production is already stressed by some authors, as it could lead to increased use of specific organic soil properties (Murphy et al.,,2008).

Oil content was significantly different among the cultivars. The lowest content was found in Kata and the highest in Nena. The rest of the cultivars were in the same group (Tab. 4). Oil content was lower in organic than in conventional conditions, but only Kata had significantly lower oil content based on an MSD of $3.5 \%$ (Tab. 4). There was no significant difference among the cultivars in protein content within farming

Table 3. Significance of farming type, sowing date and genotype on seed yield and oil and protein seed content

\begin{tabular}{cccccccc}
\hline \multirow{2}{*}{ Source of variation } & \multirow{2}{*}{ df } & \multicolumn{2}{c}{ Seed yield } & \multicolumn{2}{c}{ Oil content } & \multicolumn{2}{c}{ Protein content } \\
\cline { 3 - 8 } & & $F$ & $P r>F$ & $F$ & $P r>F$ & $F$ & $P r>F$ \\
\hline Farming (F) & 1 & 27.53 & $0.0001^{* *}$ & 6.72 & $0.011^{*}$ & 0.27 & 0.607 \\
Sowing date (S) & 2 & 11.73 & $0.0001^{* *}$ & 4.14 & $0.019^{*}$ & 1.99 & 0.143 \\
Genotype (G) & 4 & 1.57 & 0.190 & 3.03 & $0.022^{*}$ & 0.52 & 0.721 \\
F $\times$ S & 2 & 1.01 & 0.367 & 3.85 & $0.025^{*}$ & 2.45 & 0.093 \\
F $\times$ G & 4 & 1.62 & 0.176 & 1.33 & 0.266 & 1.50 & 0.210 \\
S $\times$ G & 8 & 0.89 & 0.528 & 0.86 & 0.555 & 0.67 & 0.713 \\
F $\times$ S $\times$ G & 8 & 0.38 & 0.926 & 0.49 & 0.860 & 0.98 & 0.457 \\
\hline
\end{tabular}

* Significant at the 0.05 probability level, ${ }^{* *}$ significant at the 0.01 probability level. 
Table 4. Percentage of emerged and harvested plants, seed yield, seed oil and protein content of five winter rapeseed cultivars in two farming systems averaged over sowing dates.

\begin{tabular}{ccccccc}
\hline Conventional & Banaćanka & Slavica & Nena & Kata & Jasna & Average \\
\hline Emergence $(\%)$ & 27 & 29 & 29 & 29 & 27 & 28 \\
Harvested plants $(\%)$ & 12 & 9 & 11 & 13 & 7 & 10 \\
Seed yield $\left(\mathrm{kg} / 7 \mathrm{~m}^{2}\right)$ & 0.48 & 0.24 & 0.45 & 0.48 & 0.24 & 0.38 \\
Oil $(\%)$ & 43.1 & 41.5 & 43.4 & 41.7 & 42.1 & 42.4 \\
Protein $(\%)$ & 20.2 & 20.9 & 20.2 & 21.5 & 21.1 & 20.8 \\
\hline Organic & Banaćanka & Slavica & Nena & Kata & Jasna & Average \\
\hline Emergence $(\%)$ & 41 & 44 & 45 & 45 & 36 & 42 \\
Harvested plants $(\%)$ & 16 & 18 & 14 & 14 & 15 & 15 \\
Seed yield (kg/7 $\left.\mathrm{m}^{2}\right)$ & 0.76 & 0.82 & 0.71 & 0.60 & 0.56 & 0.69 \\
Oil (\%) & 40.6 & 39.4 & 42.7 & 36.7 & 42.3 & 40 \\
Protein $(\%)$ & 20.4 & 20.8 & 21.2 & 19.4 & 21.1 & 21 \\
\hline
\end{tabular}

Table 5. Percentage of emerged and harvested plants, seed yield, oil and protein content at three sowing dates and two rapeseed farming systems averaged over cultivars

\begin{tabular}{ccccccccc}
\hline & \multicolumn{3}{c}{ Conventional } & \multicolumn{3}{c}{ Organic } \\
\hline & SD1* & SD2 & SD3 & Average & SD1 & SD2 & SD3 & Average \\
\cline { 2 - 9 } Emergence (\%) & 11 & 36 & 38 & 28 & 45 & 51 & 31 & 42 \\
Harvested plants (\%) & 11 & 14 & 7 & 10 & 21 & 15 & 11 & 15 \\
Yield $\left(\mathrm{kg} / 7 \mathrm{~m}^{2}\right)$ & 0.47 & 0.45 & 0.22 & 0.38 & 0.90 & 0.70 & 0.46 & 0.69 \\
Oil $(\%)$ & 43 & 42 & 42 & 42.4 & 41 & 42 & 37 & 40 \\
Protein $(\%)$ & 20 & 21 & 21 & 20.8 & 21 & 21 & 20 & 21 \\
\hline
\end{tabular}

*SD - Sowing date

Table 6. Tukey grouping of significantly different factor groups for seed yield and seed oil and protein content

\begin{tabular}{|c|c|c|c|}
\hline Factor & $\begin{array}{l}\text { Seed yield } \\
\left(\mathrm{kg} / 7 \mathrm{~m}^{2}\right)\end{array}$ & $\begin{array}{c}\text { Oil content } \\
(\%)\end{array}$ & $\begin{array}{c}\text { Protein content } \\
(\%)\end{array}$ \\
\hline \multicolumn{4}{|l|}{ Farming $(\mathrm{F})$} \\
\hline Conventional & $0.38^{b}$ & $42.4^{a}$ & $20.8^{a}$ \\
\hline Organic & $0.69^{a}$ & $40.3^{b}$ & $20.6^{a}$ \\
\hline \multicolumn{4}{|l|}{ Sowing date $(\mathrm{S})$} \\
\hline SD1 & $0.68^{a}$ & $42.2^{a}$ & $20.3^{a}$ \\
\hline SD2 & $0.58^{\mathrm{a}}$ & $42.1^{a}$ & $21.3^{a}$ \\
\hline SD3 & $0.34^{b}$ & $39.8^{\mathrm{b}}$ & $20.5^{a}$ \\
\hline \multicolumn{4}{|l|}{ Genotype $(\mathrm{G})$} \\
\hline Banaćanka & $0.62^{a}$ & $41.9 \mathrm{ab}$ & $20.4^{a}$ \\
\hline Slavica & $0.58^{a}$ & $40.5^{\mathrm{ab}}$ & $20.9^{a}$ \\
\hline Nena & $0.54^{\mathrm{a}}$ & $43.1^{\text {a }}$ & $20.7 \mathrm{a}$ \\
\hline Kata & $0.53^{a}$ & $39.2^{b}$ & $20.4^{a}$ \\
\hline Jasna & $0.40^{a}$ & $42.2^{\mathrm{ab}}$ & $21.2^{\mathrm{a}}$ \\
\hline
\end{tabular}

a,b different at the 0.05 probability level

systems, but Kata had significantly lower protein content in organic conditions, which together with low oil content and yield confirms that it is not suitable for organic farming. Such result of Kata may be due to selection pressure that was much more directed towards maximizing content of oleic acid rather than preserving adaptability.

Only significant difference between genotypes in emergence was found between Slavica and Jasna, and Slavica was better in both farming systems (Tab. 4). Percentage of harvested plants was significantly different between Banaćanka and Jasna in the conventional field, while in the organic conditions it was much more uniform (Tab. 4).

The effect of farming system on percentage of emerged and harvested plants, seed yield, seed oil and protein content

Ratio between the number of emerged and harvested plants was similar between two farming systems and close to $37 \%$. With a minimum significant difference (MSD) of $0.26 \mathrm{~kg}$ for the whole trial, only the farming system significantly affected yield (Tab. 5). Significant difference between the two farming systems was found for seed yield and seed oil content (Tab. 6). 
There was no significant effect on protein content. Trials dealing with organic vs conventional farming systems have also been done for other species, with various results showing yields $50 \%$ lower in organic wheat, but with higher seed quality (Mazzoncini et al., 2007). In order to improve organic rapeseed yields, it is recommended to use fertilizers with faster mineralization and to split the application during the crop cycle period (Alaru et al., 2014). However, spring $\mathrm{N}$ fertilization is not always recommended, as it does not improve yields when the preceding crop is pasture or clover (Engstrom et al., 2014).

The effect of sowing date on percentage of emerged and harvested plants, seed yield, seed oil and protein content

Depending on the region, ideal winter rapeseed SD is generally in late August or early September, so the plant parts are well-developed before the winter (Marjanović Jeromela et al., 2019). In this trial, lower seedbed quality with coarser soil structure in the conventional field strongly decreased the percentage of emerged seedlings in SD1, while the percentage of harvested plants was the lowest in SD3 in both farming systems (Tab. 5). In addition, lack of rain (data not shown) strongly decreased emergence of SD1 in both farming systems.

Tukey grouping showed that seed yield and oil content were significantly higher in SD1 and SD2 (group a) than in SD3 (group b), while there was no significant difference between SD treatments in protein content (Table 6). It seems that plants of SD3 were not developed enough for overwintering. Also, rapeseed from late sowing dates is less competitive to weeds in early spring, therefore early sowing dates are recommended for rapeseed organic production (Valantin-Morison and Meynard, 2008).

\section{Conclusion}

Based on the obtained results, early sowing date provides enough time for rapeseed growth before the winter and good overwintering. The tested rapeseed cultivars were found to have similar yield, seed oil and protein content in organic farming system. It can be concluded that the existing conventional breeding material can be a good starting point for further trait improvements in organic farming.

\section{References}

Alaru, M., Talgre, L., Eremeev, V., Tein, B., Luik, A., Nemvalts, A., Loit, E. (2014): Crop yields and supply of nitrogen compared in conventional and organic farming systems. Agricultural and Food Science, 23, 317-326.
Bernard, E., Larkin, R.P., Tavantzis, S., Erich, M.S., Alyokhin, A., Sewell, G., Lannan, A., Gross, S.D. (2012): Compost, rapeseed rotation, and biocontrol agents significantly impact soil microbial communities in organic and conventional potato production systems. Applied Soil Ecology, 52, 29-41.

Clark, A. (ed.) (2007): Managing Cover Crops Profitably. 3rd ed. National SARE Outreach Handbook Series Book 9. National Agricultural Laboratory, Beltsville, MD.

Engström, L., Stenberg, M., Wallenhammara, A.C., Ståhl, P., Gruvaeus, I. (2014): Organic winter oilseed rape response to N fertilization and preceding agroecosystem. Field Crops Research, 167, 94-101.

Haramoto, E.R. and E.R. Gallandt (2004): Brassica cover cropping for weed management: A review. Renewable Ag. and Food Sys., 19, 187-198.

Harper, F.R., Berkenkamp, B. (1975): Revised growth-stage key for Brassica campestris and B. napus. Canadian Journal of Plant Science, 55, 657-658.

Johansson, B \& Nadeau, E. (2006): Performance of dairy cows fed an entirely organic diet containing cold-pressed rapeseed cake. Acta Agriculturae Scand Section A, 56, 128-136.

Khalili, H., Kuusela, E., Saarisalo, E., Suvitie, M. (1999): Use of rapeseed and pea grain protein supplements for organic milk production. Agricultural and Food Science in Finland, 8, 239-252.

Marjanović Jeromela, A., Terzić, S., Jankulovska, M., Zorić, M., Kondić-Špika, A, Jocković, M., Hristov, N., Crnobarac, J., Nagl, N. (2019): Dissection of year related climatic variables and their effect on winter rapeseed (Brassica napus L.) development and yield. Agronomy, 9(9), 517.

Marjanović-Jeromela, A., Terzić, S., Zorić, M., Marinković, R., Atlagić, J., Mitrović, P., Milovac, Ž. (2011): Evaluation of seed and oil yield stability in NS rapeseed cultivars (Brassica napus L.). Ratarstvo i povrtarstvo, 48(1), 67-76.

Mazzoncini, M., Belloni, P., Risaliti, R., Antichi, D. (2007): Organic Vs Conventional Winter Wheat Quality and Organoleptic Bread Test. Proceedings 3rd QLIF Congress, Hohenheim, Germany, March 20-23, 2007. https://orgprints.org/9753/1/Mazzoncinietal-2007-WheatBreadQuality.pdf

Morandin, L.A., Winston, M.L. (2005): Wild Bee Abundance and Seed Production in Conventional, Organic, and Genetically Modified Canola. Ecological Applications, 15(3), 871-881.

Murphy, K., Hoagland, L., Reeves, P. \& Jones, S. (2008): Effect of cultivar and soil characteristics on nutritional value in organic and conventional wheat. Proceedings 16th IFOAM Organic World Congress, Modena, Italy, June 16-20, 2008. https:// orgprints.org/12397/

Nelder, J.A. and Wedderburn, R.W.M. (1972): Generalized Linear Models. Journal of the Royal Statistical Society A, 135, 370-384.

Pelletier, N., Arsenault, N., Tyedmers, P. (2008): Scenario Modeling Potential Eco-Efficiency Gains from a Transition to Organic Agriculture: Life Cycle Perspectives on Canadian Canola, Corn, Soy, and Wheat Production. Environmental Management, 42, 9891001.

Smith, R.F. (2005): Mustard cover crops to optimize crop rotations for lettuce production. California lettuce research board. Annual Report, 212-219.

Štrbac, P. (2005): Opšte metode prognož štetočina u biljnoj proizvodnji (General methods of pest forecasting in plant production). University of Novi Sad, Faculty of Agriculture.

Valantin-Morison, M., Meynard, J.M., Dore, T. (2007): Effects of crop management and surrounding field environment on insect incidence in organic winter oilseed rape (Brassica napus L.). Crop Protection, 26, 1108-1120.

Valantin-Morison, M., and Meynard, J.M. (2008): Diagnosis of limiting factors of organic oilseed rape yield. A survey of farmers' fields. Agron. Sustain. Dev., 28, 527-539. 


\section{Uticaj organskog i konvencionalnog sistema gajenja i datuma setve na prinos semena i sadržaj ulja i proteina u sortama uljane repice}

\section{Sreten Terzić* · Ana Marjanović Jeromela · Miroslav Zorić · Vladimir Sikora · Željko Milovac · Petar Mitrović · Igor Balalić · Velimir Radić}

Sažetak: Uljana repica je jedna od glavnih uljanih kultura koja se uzgaja u različitim agroekološkim uslovima. Interesovanje za organsku uljanu repicu raste, pri čemu je oplemenjivačima od sve većeg značaja da odrede potrebu za posebnim programima organskog oplemenjivanja. Cilj ove studije bio je utvrđivanje adaptivne vrednosti konvencionalnih sorti uljane repice u okruženjima organske poljoprivrede. Pet sorti ozime uljane repice uzgajano je na konvencionalnim i organskim parcelama, od kojih svaka sa tri datuma setve u četiri ponavljanja. Ispitivanja su organizovana korišćenjem slučajnog blok dizajna. Ispitivan je uticaj sorte i načina gajenja na nicanje, procenat požnjevenih biljaka, prinos, sadržaj ulja i proteina. Lokalno preporučene agrotehničke mere su korišćene da se polja sačuvaju od korova, insekata i bolesti. U organskom polju korov se uklanjao mehanički dok su insekti tretirani organskim insekticidom. Uzorci semena za analizu sadržaja ulja i proteina uzeti su tokom žetve. Uzimajući u obzir agrotehničke mere, ustanovljeno je da se uljana repica može uspešno gajiti u organskoj poljoprivredi, ali potrebna su dalja poboljšanja da bi se povećala stabilnost proizvodnje. Rezultati pokazuju da rana setva pruža dovoljno vremena za razvoj uljane repice pre zime i dobro prezimljavanje. Sorte su imale veći sadržaj ulja u konvencionalnom gajenju, dok nije bilo značajnog uticaja sistema gajenja na sadržaj proteina. Za sortu Slavica veći prinos je zabeležen u organskom gajenju, dok su kod oba sistema gajenja sorte Banaćanka i Nena imale visoki prinos. Rezultati upućuju na zaključak da se postojeći konvencionalno oplemenjivani materijal može koristiti kao dobra polazna tačka za dalje poboljšanje svojstava sorti u organskoj poljoprivredi.

Ključne reči: datum setve, konvencionalno, organsko, prinos semena, protein, uljana repica, ulje 